\title{
SISTEM PENDUKUNG KEPUTUSAN APLIKASI PEMILIHAN GAME ANDROID UNTUK ANAK USIA DINI
}

\author{
Miftahul Mu'alimin ${ }^{1}$, Latipah $^{2}$ \\ 1,2 Jurusan Sistem Informasi Fakultas Ilmu Komputer Universitas Narotama \\ Jln. A.R Hakim No 51 - Sukolilo Kota Surabaya \\ ${ }^{1}$ miftahul.mualimin@mhs.fasilkom.narotama.ac.id \\ ${ }^{2}$ latifah.rifani@narotama.ac.id
}

\begin{abstract}
Abstrak - Bermain game tidak hanya mendapatkan kesenangan semata namun dapat dipakai sebagai salah satu metode untuk pembentukan karakter, dan pembelajaran anak usia dini. Perkembangan game saat ini memang sangat pesat, berawal dari game konsol seperti (Game boy, SEGA, PS 1, PS 2, Xbox 360), hingga muncul game dengan sistem android. Banyaknya game yang beredar pada masyarakat menimbulkan masalah, terutama dalam pemilihan game dengan kriteria dan kebutuhan yang tepat untuk anak usia dini. Pemilihan sebuah game untuk anak usia dini dapat dilihat dari spesifikasi, jumlah pemain, harga, dan jenis gamenya. Mengkombinasikan semua hal tersebut bukanlah hal yang mudah, apalagi banyaknya game yang muncul saat ini membutuhkan waktu yang lama untuk menemukan game yang sesuai. Perancangan aplikasi Sistem Pendukung Keputusan (SPK) pemilihan game android untuk anak usia dini ini menggunakan metode Technique for Order Preference by Similiarty to Ideal Solution (TOPSIS) berdasarkan beberapa kriteria yaitu rating game, tanggal rilis, jumlah download, harga item termurah, dan ukuran download. Aplikasi yang dirancang bertujuan untuk membantu pemain memilih game dengan tepat dan cepat. Hasil rancangan aplikasi ini diharapkan dapat membantu para pengguna khususnya orang tua untuk memilih game terbaik untuk anak-anak mereka. Diharapkan hasil rancangan ini kemudian akan dilanjutkan dengan membangun aplikasi SPK sehingga dapat bermanfaat untuk para pencinta game
\end{abstract}

Kata kunci : Anak, android, game, SPK, Topsis.

\section{PENDAhuluan}

Bermain game merupakan salah satu cara bagi beberapa penduduk di muka bumi ini untuk melepas jenuh, berinteraksi dengan teman, bahkan ada yang bersungguh-sungguh dalam bermain game, sehingga mereka dapat menjadi atlet $e$-sport yang mewakili wilayah tertentu untuk bertanding dalam kompetisi game yang sesuai dengan game yang dimainkannya.

Tidak dapat dipungkiri lagi, bahwa perkembangan game saat ini memang sangat pesat, yang berawal dari konsol game seperti (GameBoy, SEGA, PS 1, PS 2, XBOX 360) hingga saat ini telah muncul game dengan sistem operasi Android, dimana disini pengguna dapat mengakses game yang digemarinya lewat Tablet / ponsel pintar yang dimiliki oleh pengguna. Semakin banyak dan pesat game tersebut berkembang, semakin banyak pula pilihan game yang ditawarkan oleh para developer game untuk para pengguna sistem operasi Android. Sistem Operasi Android ini merupakan sistem operasi yang banyak digunakan untuk ponsel pintar yang dimiliki masyarakat Indonesia, mengalahkan sistem operasi yang lain salah satunya $i O S$. Karena semakin banyak game yang ditawarkan didalam ponsel pintar yang memiliki sistem operasi Android, ada beberapa orang yang masih kesulitan dalam memilih game yang sesuai dengan kriteria yang diinginkannya.

Oleh karena itu penulis bertujuan untuk membuat sebuah sistem pendukung keputusan pemilihan game Android untuk anak usia dini dengan menggunakan metode TOPSIS yang bertujuan untuk mempermudah pengguna khususnya orang tua dalam memilih game ponsel pintar yang sesuai dengan kriteria yang dibutuhkan untuk sang buah hatinya. Menurut Muzakkir (2017) metode TOPSIS ini akan menghasilkan solusi ideal positif dan memiliki jarak terjauh dengan solusi ideal negative, sehingga hasil atau output dari sistem ini adalah data game yang berasal dari proses pencarian pengguna dalam menentukan kriteria yang cocok untuk menentukan alternatif terbaik bagi user. Aplikasi ini juga menghasilkan perangkingan alternatif game yang terbaik hingga paling buruk sesuai dengan kriteria dan pembobotan yang dimasukkan user sebelumnya. Dengan begini diharapkan pengguna dapat terbantu dalam proses pemilihan game, khususnya pengguna untuk sistem operasi Android. 


\section{Metodologi Penelitian}

\section{Sistem Pendukung Keputusan}

\subsection{Definisi}

Pada dasarnya sistem pendukung keputusan merupakan sistem yang digunakan untuk membantu pengguna dalam proses pengambilan keputusan, dengan memanfaatkan data dan pemodelan sistem yang dibentuk untuk memenuhi kebutuhan penggunanya dalam memecahkan masalah yang ada (Saliman, 2015). Konsep sistem pendukung keputusan dapat diterapkan pada pemilihan perguruan tinggi (Hylenarti Hertyana, 2019), pemilihan objek wisata (Wira Trise Putra et al., 2020), pendukung pemilihan smartphone terbaik (Eryzha et al., 2019), pemilihan smartphone android gaming (Rahmatullah et al., 2018), bahkan untuk penentuan keluarga miskin di desa (Muzakkir, 2017).

\subsection{Tahapan Sistem Pendukung Keputusan}

Menurut Herbert A, Simon (1960) terdapat 4 tahap dalam proses pengambilan keputusan yaitu:

1. Penelusuran (intelligence)

Tahapan ini merupakan penelusuan suatu masalah serta mengidentifikasikan suatu informasi yang dibutuhkan dalam proses membuat sebuah keputusan yang akan diambil.

2. Perancangan (design)

Pada tahap ini terdapat analisa dalam membuat sebuah rumusan alternatif pemecahan masalah.

3. Pemilihan (choice)

Tahapan ketiga merupakan tahapan pemilihan sebuah solusi yang diharapkan paling sesuai dengan penanganan masalah yang ada.

4. Impelementasi (Implementation)

Terakhir merupakan tahapan implementasi untuk melaksanakan keputusan yang telah diambil.

\section{Technique for Order Preference by Similarity to deal Solution (TOPSIS)}

TOPSIS merupakan metode pendukung keputusan multikriteria yang memiliki konsep bahwa alternatif terbaik merupakan alternatif yang memiliki jarak terpendek dengan solusi ideal positif serta memiliki jarak terpanjang dari solusi ideal negative (Rahmayani \& Irawan, 2016). Metode ini diperkenalkan pertama kali oleh Yoon \& Hwang (1995) dengan tahapan dalam metode TOPSIS adalah sebagai berikut :

a. Membuat matriks keputusan yang ternormalisasi

$$
r_{i j}=\frac{i j}{\sqrt{\sum_{i}^{m} x^{2} x_{i j}^{2}}}
$$

Dimana :

rij $=$ hasil dari normalisasi matriks

$\mathrm{i}=1,2,3, \ldots \mathrm{m}$;

$\mathrm{j}=1,2,3, \ldots \mathrm{n}$;

xij = elemen dari matriks keputusan b. Membuat matriks keputusan normalisasi terbobot

$V=\left[\begin{array}{ccc}w_{11} r_{11} & \cdots & w_{1 n} r_{1 n} \\ \vdots & \ddots & \vdots \\ w_{m 1} r_{m 1} & \cdots & w_{n m} r_{n m}\end{array}\right]$

Dimana :

$$
\begin{aligned}
W & =(w 1, w 2, \ldots, w n) \\
r & =(r 1, r 2, \ldots, r n) \\
V & =\text { Bobot Matriks }
\end{aligned}
$$

c. Menentukan solusi ideal positif dan solusi ideal negatif

$$
\begin{aligned}
& A^{+}=\left\{\left(\max _{V i j}\right)\left(\min _{V i j} \mid J \in J^{\prime}\right), i=1,2,3 \ldots m\right\}= \\
& \left\{V_{1}^{+}, V_{2}^{+}, \ldots V_{m}^{+}\right\} \\
& A^{-}=\left\{\left(\max _{V i j}\right)\left(\min _{V i j} \mid J \in J^{\prime}\right), i=1,2,3 \ldots m\right\} \\
& =\left\{V_{1}^{-}, V_{2}^{-}, \ldots V_{m}^{-}\right\} \text {. }
\end{aligned}
$$

Dimana :

A $+=$ Solusi ideal positif

A- $=$ Solusi ideal negatif

$\mathrm{V}$ ij = Elemen matriks $\mathrm{V}$ baris ke-i dan kolom ke-j

$\mathrm{J}=$ Kriteria benefit

$\mathrm{J}^{\prime}=$ Kriteria $\cos t$

d. Menentukan Separasi

$$
S_{i}^{+}=\sqrt{\sum_{j-i}^{n}\left(v_{i j}-v_{j}^{+}\right)^{2}} \text {, dengan } i=1,2,3 \ldots, m \quad \ldots \ldots
$$

Dimana :

$S_{i}^{+}=$Jarak untuk solusi ideal positif

$\mathrm{J}=$ Kriteria Benefit

$\mathrm{J}^{\prime}=$ Kriteria Cost

$\mathrm{V} \quad=$ Elemen matriks

$$
=\sqrt{\sum_{j-i}^{n}\left(v_{i j}-v_{j}^{-}\right)^{2}} \text {, dengan } i=1,2,3 \text {. }
$$

$$
\begin{array}{ll}
S_{i}^{-} & =\text {Jarak untuk solusi ideal negatif } \\
\mathrm{J} & =\text { Kriteria Benefit } \\
\mathrm{J}, & =\text { Kriteria Cost } \\
\mathrm{V} & =\text { Elemen matriks }
\end{array}
$$

e. Menentukan kedekatan relative

$$
C 1=\frac{s_{i}^{-}}{S_{i}^{-}+S_{i}^{+}} \text {. }
$$

$\mathrm{Si}+=$ Jarak untuk solusi ideal positif

$S_{i}^{-}=$Jarak untuk solusi ideal negative

f. Menentukan ranking alternatif 
Alternatif yang ada dapat diranking berdasarkan urutan dari kedekatan relative

\section{Use Case Diagram}

Menurut Rosadi dan Khotijah (2017) Use case diagram pada rancangan aplikasi SPK,terdapat 2 aktor yaitu user dan admin terlihat pada gambar 1 berikut ini.

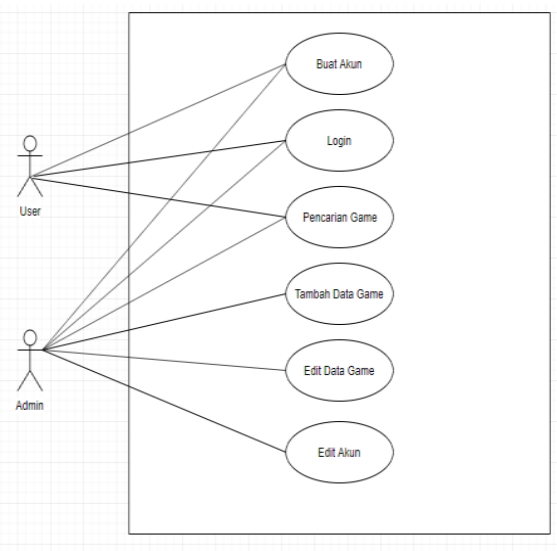

Gambar 1. Use Case Diagram

\section{Activity Diagram}

Activity diagram memodelkan alur kerja (workflow) proses dan urutan aktivitas dalam suatu proses (Pahlevi \& Istoningtyas, 2018). Diagram ini mirip dengan flowchart karean dapat dimodelkan dari satu aktivitas ke aktivitas lainnya (Sulistyorini, 2009)

a. Activity Diagram Buat Akun User

Gambar 2 Menjelaskan mengenai Activity Diagram Buat Akun User, dimana proses pertama yang dilakukan user adalah masuk kehalaman awal login, kemudian user memilih buat akun baru yang tersedia pada pilihan menu di halaman awal login.

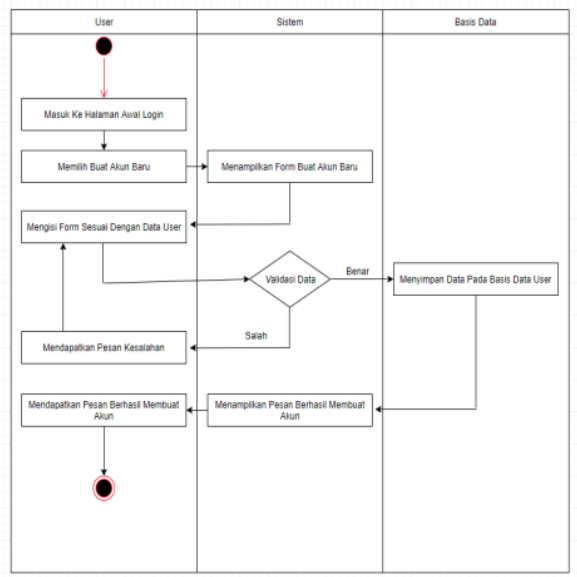

Gambar 2. Activity Diagram Buat Akun User

b. Activity Diagram Login User
Gambar 3 menjelaskan tentang Activity Diagram Login User dimana proses pertama user adalah masuk kehalaman awal login, kemudian menginput data user untuk login.

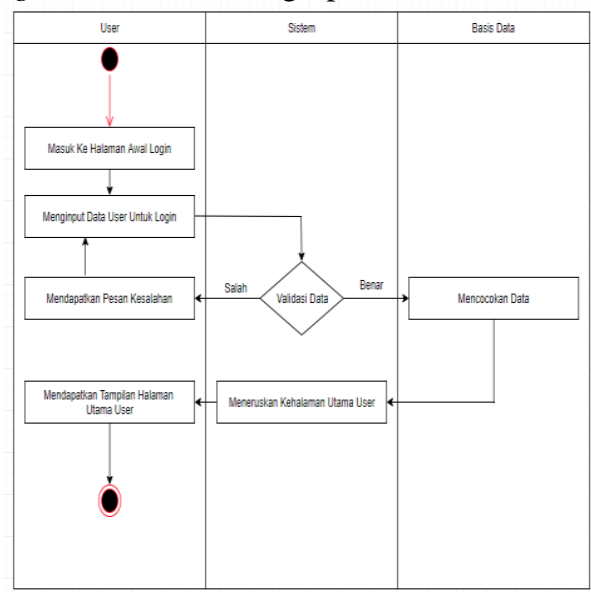

Gambar 3. Activity Diagram Login User

c. Activity Diagram Pencarian Game User

Sesuai dengan Gambar 4 yang menjelaskan mengenai Activity Diagram Pencarian Game User. Hal pertama yang dilakukan user adalah melakukan proses login user, kemudian memilih menu pencarian pada halaman utama user setelah itu sistem akan meneruskan menuju halaman pencarian game sehingga user akan mendapatkan tampilan halaman pencarian game

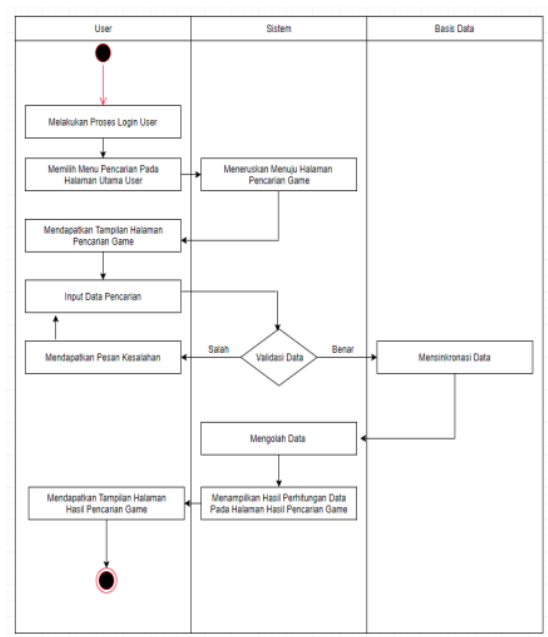

Gambar 4. Activity Diagram Pencarian Game User

\section{Sequence Diagram}

Sequence diagram ialah diagram yang menggambarkan interaksi objek yang disusun dalam suatu urutan waktu (Mangunson, 2017). Sequnce diagram digunakan untuk menggambarkan perilaku pada sebuah aplikasi dan 
mendeskripsikan bagaimana entitas dan sistem berinteraksi (Siregar \& Melani, 2019).

a. Sequence Diagram Buat Akun User

Pada Gambar 5 menjelaskan mengenai Sequence Diagram membuat akun untuk aktor user, langkah awal user untuk membuat akun tersebut adalah memilih buat akun baru.

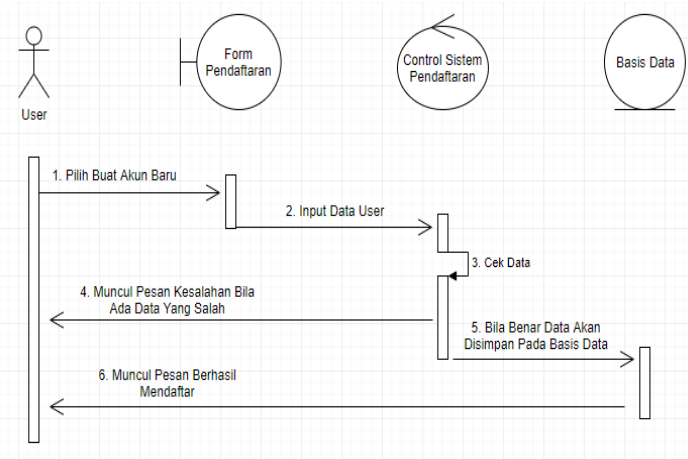

Gambar 5. Sequence Diagram Login User

b. Sequence Diagram Login User

Gambar 6 menjelaskan tentang Sequence Diagram Login User, pertama - tama user masuk kedalam form login, kemudian user menginput data sesuai dengan data yang sudah didaftarkan dalam membuat akun.

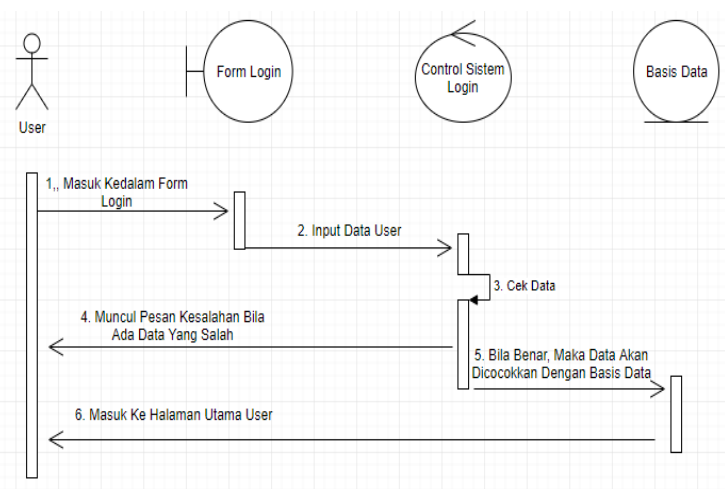

Gambar 6. Sequence Diagram Login User

c. Sequence Diagram Pencarian Game User

Pada Gambar 7 menjelaskan tentang Sequence Diagram Pencarian Game User dimana langkah awal user adalah memilih menu pencarian pada halaman utama user.

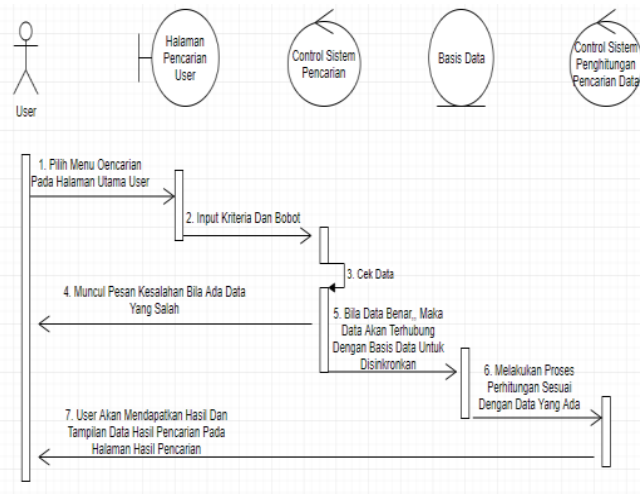

Gambar 7. Sequence Diagram Pencarian Game User

\section{HASIL DAN PEMBAHASAN}

Hasil sistem dapat didefinisikan sebagai penguraian dari suatu sistem informasi yang utuh kedalam bagian komponennya dengan maksud untuk mengevaluasi masalah yang ada (Iskandar \& Akhiyar, 2020). Berikut sebuah contoh sederhana proses metode Technique for Order Preference by Similarity to deal Solution dalam melakukan penilaian :

\section{Pembobotan Kriteria}

Untuk menentukan rangking dari masing-masing alternative, maka terlebih dahulu dilakukan pembobotan. Adapun penentu bobot kepentingan dari setiap kriteria dibentuk dalam tabel 1.

Tabel I. Kriteria

\begin{tabular}{ccc}
\hline \multicolumn{3}{c}{ Tabel I. Kriteria } \\
\hline Keterangan & Bobot & Kriteria \\
\hline Rating Game & 5 & K1 \\
\hline Tanggal Rilis & 1 & K2 \\
\hline Paling Banyak Didownload & 4 & K3 \\
\hline Harga Item Termurah & 3 & K4 \\
\hline Ukuran Download Game & 3 & K5
\end{tabular}

Pada penelitian ini model penilaian terdiri dari 5 kriteria seperti berikut .

a) Pada Tabel 2 menentukan nilai konversi dari rating game,semakin baik rating game semakin baik nilai konversi.

Tabel II. Konversi kriteria Rating Game

\begin{tabular}{cc}
\hline Rating & Nilai Konversi \\
\hline$\leq 3,5$ & 5 \\
\hline$>3,5-\leq 3,7$ & 4 \\
\hline$>3,7-\leq 4,0$ & 3 \\
\hline$>4,0-\leq 4,4$ & 2 \\
\hline$>4,4$ & 1 \\
\hline
\end{tabular}


b) Pada Tabel 3 menentukan nilai koneversi dari kriteria tanggal rilis,semakin terbaru game akan mendapat nilai konversi baik.

Tabel III. Konversi kriteria Tanggal Rilis

\begin{tabular}{cc}
\hline Tanggal Rilis Game & Nilai Konversi \\
\hline$\leq$ Desember 2012 & 5 \\
\hline $\begin{array}{c}2014 \\
\text { >Desember } 2013-\leq \text { Desember } \\
2014-\leq \text { Desember }\end{array}$ & 4 \\
\hline$>$ Desember 2018 Desember $2018-\leq$ Desember \\
2019 & 3 \\
\hline >Januari 2020 & 2 \\
\hline
\end{tabular}

c) Pada Tabel 4 menentukan konversi kriteria dari jumlah banyaknya download game.

Tabel IV. Konversi kriteria Jumlah Download

\begin{tabular}{cc}
\hline Jumlah Download & Nilai Konversi \\
\hline$\leq 500,000$ & 5 \\
\hline$>500,000-\leq 1,000,000$ & 4 \\
\hline$>1,000,000-\leq 5,000,000$ & 3 \\
\hline$>5,000,000-\leq 15,000,000$ & 2 \\
\hline$\geq 15,000,000$ & 1 \\
\hline
\end{tabular}

d) Pada Tabel 5 menjelaskan bagaimana mengkoversi kriteria hara item termurah

Tabel V. Konversi kriteria harga item termurah

\begin{tabular}{|c|c|}
\hline Harga Item Termurah & Nilai Konversi \\
\hline$\leq 3,000$ & 5 \\
\hline$>3,000-\leq 10,000$ & 4 \\
\hline$>10,000-\leq 20,000$ & 3 \\
\hline$>20,000-\leq 35,000$ & 2 \\
\hline$>35,000$ & 1 \\
\hline
\end{tabular}

e) Pada Tabel 6 menentukan nilai konversi dari kriteria ukuran download game.

Tabel VI. Konversi kriteria ukuran download game

\begin{tabular}{|c|c|}
\hline Ukuran Download & Nilai Konversi \\
\hline$\leq 10 \mathrm{MB}$ & 5 \\
\hline$>10 \mathrm{MB}-\leq 50 \mathrm{MB}$ & 4 \\
\hline$>50 \mathrm{MB}-\leq 100 \mathrm{MB}$ & 3 \\
\hline$>100 \mathrm{MB}-\leq 200 \mathrm{MB}$ & 2 \\
\hline$>200 \mathrm{MB}$ & 1 \\
\hline
\end{tabular}

f) Tabel 7 Contoh Data game yang diambil dari play store sebagai perhitungan SPK dengan metode TOPSIS.

Tabel VII. Data Alternatif

\begin{tabular}{|c|c|c|c|c|c|}
\multicolumn{1}{|c|}{ Tabel VII. Data Alternatif } \\
$\begin{array}{c}\text { Data } \\
\text { Atribut }\end{array}$ & K1 & K2 & K3 & K4 & K5 \\
\hline Pictionary & 3,7 & $\begin{array}{c}\text { Mei } \\
2019\end{array}$ & $\begin{array}{c}\text { Didownload } \\
500,000 \\
\text { Kali }\end{array}$ & Rp. 0 & $\begin{array}{c}119 \\
\text { MB }\end{array}$ \\
\hline $\begin{array}{c}\text { Polisi } \\
\text { Panda }\end{array}$ & 4,2 & $\begin{array}{c}\text { Mei } \\
2017\end{array}$ & $\begin{array}{c}\text { Didownload } \\
50,000,000 \\
\text { Kali }\end{array}$ & $\begin{array}{c}\text { Rp. } \\
3,000\end{array}$ & $\begin{array}{c}87 \\
\text { MB }\end{array}$ \\
\hline $\begin{array}{c}\text { Game } \\
\text { Matematika }\end{array}$ & 4,4 & $\begin{array}{c}\text { Agustus } \\
2017\end{array}$ & $\begin{array}{c}\text { Didownload } \\
10,000,000 \\
\text { Kali }\end{array}$ & $\begin{array}{c}\text { Rp. } \\
26,000\end{array}$ & $\begin{array}{c}7,5 \\
\text { MB }\end{array}$ \\
\hline $\begin{array}{c}\text { Kids } \\
\text { Puzzles }\end{array}$ & 4,0 & $\begin{array}{c}\text { Novem } \\
\text { ber } \\
2018\end{array}$ & $\begin{array}{c}\text { Didownload } \\
1,000,000 \\
\text { Kali }\end{array}$ & $\begin{array}{c}\text { Rp. } \\
28,000\end{array}$ & $\begin{array}{c}32 \\
\text { MB }\end{array}$ \\
\hline $\begin{array}{c}\text { Baby Shark } \\
\text { Run Away }\end{array}$ & 4,2 & $\begin{array}{c}\text { Desemb } \\
\text { er } 2020\end{array}$ & $\begin{array}{c}\text { Didownload } \\
10,000 \text { Kali }\end{array}$ & $\begin{array}{c}\text { Rp. } \\
16,000\end{array}$ & $\begin{array}{c}48 \\
\text { MB }\end{array}$ \\
\hline
\end{tabular}

Adapun tahapan perhitungan dengan metode TOPSIS dengan mengunakan sistem sebagai berikut

Langkah 1. Pada Gambar 8 mejelaskan dari data Alternatif yang ada pada Tabel 7 dikonversi dengan bobot yang kita tentukan.

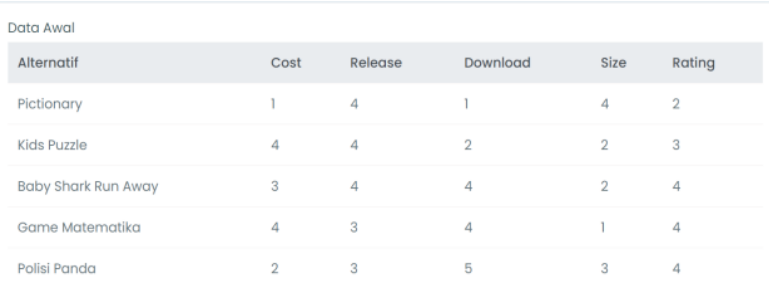

Gambar VIII. Data awal setelah di konversi

Langkah 2. Menentukan matriks yang menentukan nilai keputusan ternomalisasi,hasil seperti di Gambar 9

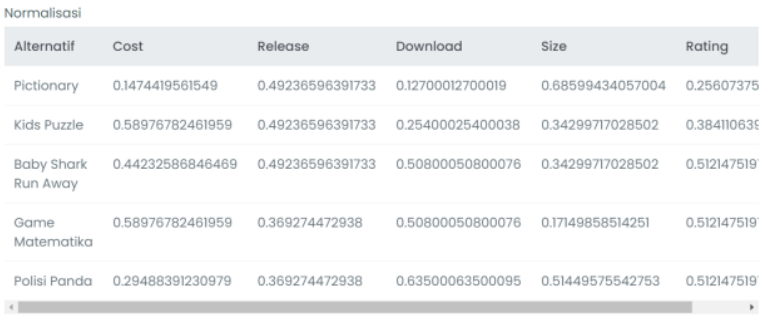

Gambar IX. Nilai Ternomalisasi

Langkah 3. Pada Gambar 10 Menentukan matriks nilai keputusan ternomalisasi terbobot 


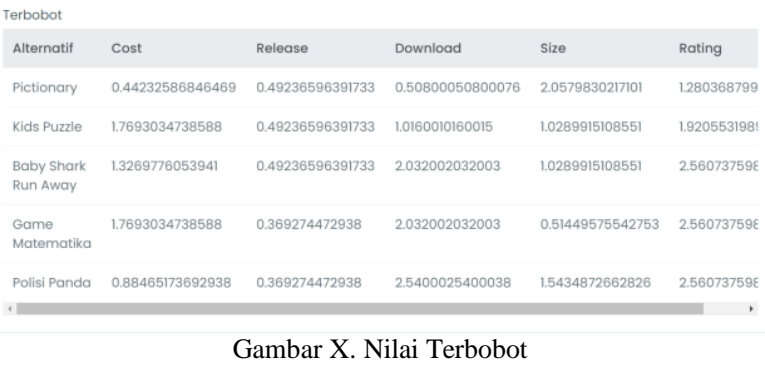

Langkah 4. Pada Gambar 11 menetukan hasil dimana solusi ideal Postive (A+) dan solusi ideal negative (A-)

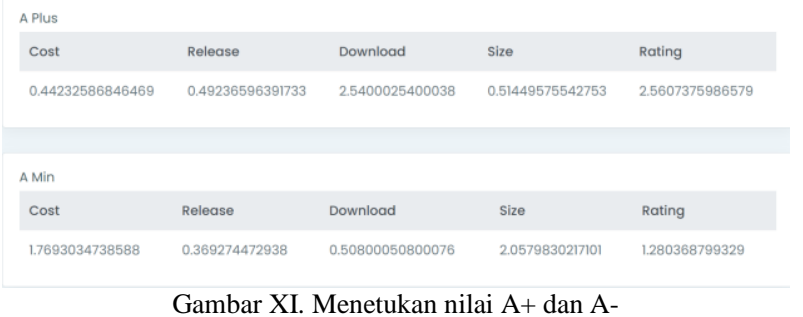

Langkah 5. Menentukan hasil separasi dimana $S_{i}^{+}=$Jarak untuk solusi ideal positif dan $S_{i}^{-}=$Jarak untuk solusi ideal negatif. Hasil seperti pada Gambar 12 dan 13

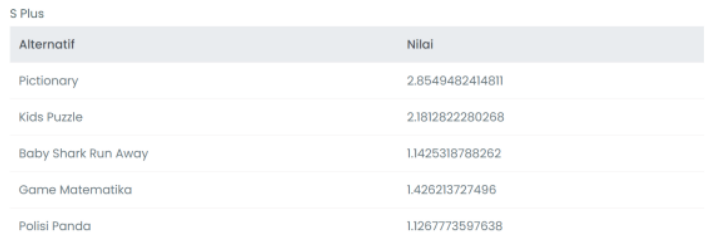

Gambar XII. Menetukan nilai S+

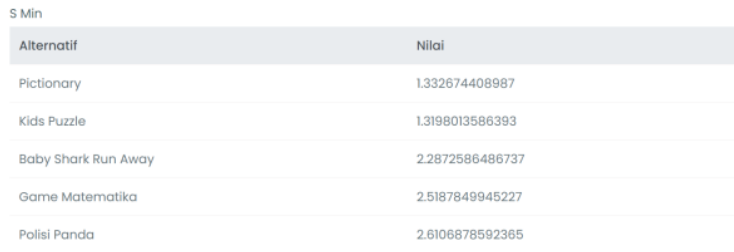

Gambar XIII. Menetukan nilai S-

Langkah 6. Kemudian menentukan peringkat berdasarkan nilai preferensi dari setiap alternatif yang sudah dihitung sebelumnya. Berikut hasil peringkat setiap alternatif. Pada Gambar 14 dan Gambar 15

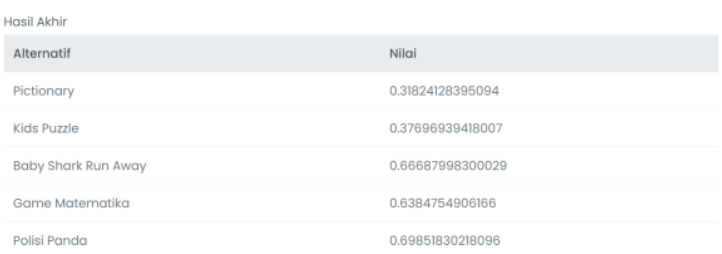

Gambar XIV. Nilai akhir

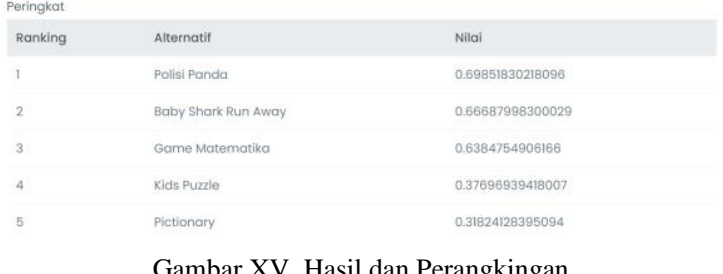

\section{KESIMPULAN}

Perancangan aplikasi sistem pendukung keputusan pemilihan game untuk anak usia dini dengan metode topsis untuk proses perhitungan nilai akhir setiap alternatif sesuai dengan yang diharapkan sistem, sehingga dapat membantu orang dalam memilihkan game untuk anak sesuai kriteria yang telah ditentukan. Hasil pengujian kualitas software secara keseluruhan menunjukkan kualitas aplikasi sistem pendukung keputusan pemilihan game memiliki kriteria yang baik yaitu $75 \%$.

Sistem pendukung keputusan pemilihan game untuk anak usia dini di masa yang akan datang diharapkan dapat diintegrasikan dengan sistem pemilihan game anak lainnya sehingga dapat memudahkan dalam memilih game anak yang terbaik berdasarkan kriteria yang diinginkan.

Penelitian selanjutnya diharapkan dapat mengkombinasikanlebih banyak metode dalam analisa data dan penyelesaian masalah sehingga didapat sebuah model sistem pendukung keputusan yang lebih efektif dalam pengolahan atau penyajian informasi.

\section{UCAPAN TERIMA KASIH}

Terimakasih kami ucapkan kepada semua pihak yang telah membantu perancangan aplikasi ini, mulai dari orang tua, saudara, dosen pembimbing, dan juga teman-teman terdekat. Semoga perancangan aplikasi ini dapat bermanfaat bagi pembaca.

\section{REFERENSI}

[1] Eryzha, A., Solikhun, S., \& Irawan, E. (2019). Sistem pendukung keputusan rekomendasi pemilihan smartphone terbaik menggunakan metode topsis. Komik (Konferensi Nasional Teknologi Informasi Dan Komputer), 3(1). https://doi.org/10.30865/komik.v3i1.1668

[2] Hylenarti Hertyana. (2019). Sistem Pendukung Keputusan Seleksi Pemilihan Perguruan Tinggi Menggunakan Metode TOPSIS. Juenal PILAR Nusa Mandiri, 15.

[3] Iskandar, R., \& Akhiyar, D. (2020). Perancangan Sistem Informasi Pelayanan Klinik Alidza Kota Padang Berbasis Web. 27, 77-83.

[4] Mangunson, P. (2017). Aplikasi Game Catur Multiplayer Via Bluetooth Berbasis Android. 5(2), 118-127.

[5] Muzakkir, I. (2017). Penerapan Metode Topsis Untuk Sistem Pendukung Keputusan Penentuan Keluarga Miskin Pada Desa Panca Karsa Ii. ILKOM Jurnal Ilmiah, 9(3), 
274-281. https://doi.org/10.33096/ilkom.v9i3.156.274-281

[6] Pahlevi, M. R., \& Istoningtyas, M. (2018). Perancangan Sistem Informasi Akademik Prodi Magister Sistem Informasi STIKOM Dinamika Bangsa Jambi. Jurnal Ilmiah Media SISFO, 12(1). http://ejournal.stikomdb.ac.id/index.php/mediasisfo/article/view/337/273

[7] Rahmatullah, S., Silvi Purnia, D., \& Hariyadi, R. (2018). Sistem Pendukung Keputusan Pemilihan Smartphone Android Gaming dengan Metode Analytical Hierarchy Process. 18(3).

[8] Rahmayani, A., \& Irawan, M. (2016). Perancangan Dan Implementasi Perangkat Lunak Sistem Pendukung Keputusan Multi Kriteria Menggunakan Metode Topsis. Jurnal Sains Dan Seni ITS, 5(2). https://doi.org/10.12962/j23373520.v5i2.17163

[9] Rosadi, D., \& Khotijah, S. (2017). Jurnal computech dan bisnis. Jurnal Computech \& Bisnis, 11(1), 39-46. http://jurnal.stmik-mi.ac.id/index.php/jcb/article/view/156

[10] Saliman, S. (2015). Mengenal DEcision Support System (DSS). Efisiensi - Kajian Ilmu Administrasi, 10(1). https://doi.org/10.21831/efisiensi.v10i1.3971

[11] Simon, H. A. (1960). The New Science of Management Decision. Harper and Row.

[12] Siregar, H. F., \& Melani, M. (2019). Perancangan Aplikasi Komik Hadist Berbasis Multimedia. Jurnal Teknologi Informasi, 2(2), 113. https://doi.org/10.36294/jurti.v2i2.425

[13] Sulistyorini, P. (2009). Pemodelan Visual dengan Menggunakan UML dan Rational Rose. Jurnal Teknologi Informasi DINAMIK Volume, XIV(1), 23-29.

[14] Wira Trise Putra, D., NoviaSanti, S., Yoga Swara, G., \& Yulianti, E. (2020). Metode topsis dalam sistem pendukung keputusan pemilihan objek wisata. 8(1). https://doi.org/10.21063/JTIF.2020.V8.1

[15] Yoon, K. P., \& Hwang, C. L. (1995). Multiple Attribute Decision Makin: An Introduction Publications, Thousand Oaks, $C A$. 